relocation has not been the case here. ${ }^{23}$

On the whole, phoebes are extremely adaptable to man and his works. Forbush and May cite several instances of their nesting in strange situations, such as in an old colander hung on a barn wall, or in a well where a knothole in the lid was used as an entrance. ${ }^{3}$ And Bent records one previous instance of their nesting around a lamp socket, although there the nest was partly supported by a wire.' Both studies refer to the birds becoming accustomed to the daily occurrence of people passing by.

This nest site, besides having ample overhanging eaves, has one additional feature which recommends it. It is near water, for a slough with a built-in dugout is but a few hundred metres from the house. The water provides a good hatch of insects, and flying insects are a phoebe's chief food. The light bulb's be- ing turned on occasionally during twilight even attracts food close to the nest. The slough also provides mud for nest building and repair, and water for bathing. The Eastern Phoebe is "a great bather."3

The distractions, then, of slamming doors and flicking lights have not deterred this friendly little bird from being, as Chapman says, "a devoted parent . . . rarely found far from home.""

BENT, A. C. 1963 (reprint of 1942). Life histories of North American flycatchers, larks, swallows, and their allies. New York, Dover. 555 pp.

${ }^{2}$ CHAPMAN, F. M. 1937. Handbook of birds of eastern North America. New York, D. Appleton-Century. 581 pp.

${ }^{3}$ FORBUSH, E. H., and J.R. MAY. 1939. Natural history of the birds of eastern and central North America. Boston, Houghton Mifflin. 554 pp.

\title{
CARDINAL AT SYLVAN LAKE, ALBERTA
}

\author{
W. B. PARSONS, MD, Box 418, Sylvan Lake, Alberta. TOM 1 Z0
}

On 26 June at 1530 hours my wife and I were having tea when she said, "There's a bird I don't recognize. It looks as if it has a black eye."

I moved to the window, then gasped. I had seen this bird down east. The dark area at the base of the bill extending up to the eye from the heavy reddish bill plus the crest are characteristic of the Cardinal, this one a female, the red muted, the body a soft sort of golden brown. She was $3 \mathrm{~m}$ from us, pecking at some hay mulch on a rose bed. She was there long enough for us to study her with field glasses and to see the faint red in the crest, wings and tail; and to see our sighting duplicated in five bird books: Gilbert Pearson, Godfrey, Peter- son, Audubon and Robbins et al. None of them mentions a sighting closer than southeast Saskatchewan though a friend of mine saw a male on the north side of this lake in 1981 but didn't report it.

For more than a quarter century we have tried, with considerable success, to attract birds to our 85 lakeshore acres of cropland, pasture and woodlot. It seems that when passing birds see the large number here they decide that it's a safe place to stop, so the number and variety grow. Unhappily, I didn't get a picture of the cardinal so this sighting will classify as hypothetical, but I am convinced of its authenticity. 